\title{
Methods of Calculating the Individual Heating Costs in Multi-Family Buildings in Selected Countries ${ }^{\dagger}$
}

\author{
Nataliia Olha Kozydra ${ }^{1}$, Mariusz Adamski ${ }^{1, *}$ and Vasyl Zhelykh ${ }^{2}$ \\ 1 Faculty of Civil and Environmental Engineering, Bialystok University of Technology, Wiejska 45A, 15-351 \\ Bialystok, Poland \\ 2 Faculty of Civil Engineering, Czestochowa University of Technology, Akademicka 3, 42-200 Częstochowa, \\ Poland \\ * Correspondence: mariusz.adamski@pb.edu.pl; Tel.: +48-797-995-925 \\ † Presented at Innovations-Sustainability-Modernity-Openness Conference (ISMO'19), Bialystok, Poland, \\ 22-23 May 2019.
}

Published: 5 July 2019

\begin{abstract}
This paper presents the methods used to determine individual heating costs in Germany, Austria, Poland, and Ukraine, as well as EU arrangements for the settlement of individual heating costs. Also presented is the original method, which significantly eliminates excessive inequalities in individual charges for central heating - so-called chimneys in the settlements of individual costs for flats heating.
\end{abstract}

Keywords: heating costs; heat cost allocator; energy law

\section{Introduction}

The calculation of individual heating costs in multi-family apartments takes place in accordance with the provisions of individual housing cooperatives. Calculations are usually made by billing companies. The calculations must comply with countries' energy legislations. Several common methods for calculating payments for the heating of individual apartments are listed below.

(1) The method most often used in settlements: i.e., the method in which the share of readings of cost allocators from a given apartment is calculated according to the sum of readings in a given unit of account. This method makes assumptions in regard to what portion of the receivables is settled on the surface of flats, and what portion is settled on the cost allocators. It is usually assumed that $50 \%$ of the total heating costs are settled on the surface of flats, with the remaining $50 \%$ settled on the heat cost allocators. Also, $60 \%$ and even $80 \%$ of total heating costs are settled on the surface of flats. Hence, the price of the heat unit is determined. This method overestimates the heat unit price and may lead to irrationally large heating payments for each $1 \mathrm{~m}^{2}$ of individual dwellings [1,2]. In some cases, even upwards of $90 \%$ of the total heating cost needs to be settled on the surface of flats in order to get a reasonable price for a heat unit;

(2) The method based on the VDI 2077 standard: this method compares the sum of the cost allocator's indications with the value resulting from the readings from the heat meter. Unregistered heat units are added to individual apartments proportionally to the area of these apartments. The $\boldsymbol{r}_{\boldsymbol{w}}$ parameter is determined. If the $\boldsymbol{r}_{\boldsymbol{w}}$ value is less than 0.34 , unregistered heat units must be added to obtain receivables reflecting the heating costs. Usually, the allocators do not measure the amount of heat transferred to the room by the radiator [2,3];

(3) The Austrian method: in this method, the heat transferred from pipes to rooms is calculated and converted into heat units and summed with values resulting from the indications of heat cost allocators [4]; 
(4) The new method based on the price of a heat unit, which results from the properties of electronic cost allocators and heat energy prices [1,4].

\section{Materials and Methods}

According to the calculation principles used in Germany, Austria, Poland, and Ukraine (Table 1), calculations were made for the selected building [4]. The new calculation method was also used [1].

Table 1. Comparison of parameter values used the in methods for determining individual heating costs.

\begin{tabular}{ccccc}
\hline Method No. & Country/Method: & Laf Values & $\mathbf{1} \mathbf{~ c v} \approx \mathbf{1} \mathbf{k W h}$ & $\begin{array}{c}\text { The Division of Costs } \\
\text { Settled on } \mathbf{~ m}^{2} \text { and } \mathbf{~ c v}\end{array}$ \\
\hline 1 & Germany & $=1$, constant & apply & constant value \\
2 & Austria & $\leq 1$, calculated & apply & constant value \\
3 & Poland & $\leq 1$, calculated & not apply & constant value \\
4 & Ukraine & $\leq 1$, calculated & no apply & constant value \\
5 & Authors' method & $=1$ or $\leq 1$, calculated & apply & calculated value \\
\hline
\end{tabular}

The value of heat registered by the heat meter, marked $K_{H W}$, is the product of the heat consumption value $Q_{H W}$ in GJ or Gcal registered by the heat meter and the heat price $\boldsymbol{c}_{\boldsymbol{c}}$ (e.g., $\left.€ / G J\right)$, that is:

$$
K_{H W}=c_{c} \cdot Q_{H W}
$$

Heat price $\boldsymbol{c}_{\boldsymbol{c}}$ is the sum of heat and heat delivery costs. These prices and registered heat quantities are given on invoices from the heat supplier.

\section{Results}

The analysis based on the VDI 2077 standard of the correctness of the indications of electronic cost allocators indicates that the dividers do not always register values properly. Usually, cost allocators register too little. According to VDI 2077, if the value of parameter $\boldsymbol{r}_{\boldsymbol{w}}$ is less than 0.43 , the missing virtual units of heat should be added according to the following equation $[5,6]$ :

$$
\Delta z=\left(0.43-r_{w}\right) \cdot Q_{H W} \cdot E_{B}
$$

The added heat units are distributed proportionally to the surface of the dwellings and added to the heat consumption value read from the cost allocators.

The half of the heating costs $0.5 K_{H W}$ is settled on the basis of the surface of flats. The other half (which is also $0.5 K_{H W}$ ) is settled based on the heat cost allocators. With the addition of missing units of the heat $\Delta z$ to the value of parameter 0.43 , we get the total number of units $z$ for settlements:

$$
z=r_{w} \cdot Q_{H W} \cdot E_{B}+\Delta z=0.43 \cdot Q_{H W} \cdot E_{B} .
$$

The price of a unit of heat results from the following equation:

$$
c_{1}=\frac{\text { the amount settled by allocators }}{\text { the number of heat units included }}
$$

From here we get the price of a heat unit:

$$
c_{1}=\frac{0.5 K_{H W}}{Z}=\frac{0.5 c_{c} Q_{H W}}{0.43 \cdot Q_{H W} \cdot E_{B}}=1.1628 \quad c_{c} \frac{1}{E_{B}}
$$

Regarding the virtual heat units, $\Delta z$ significantly reduces the price of a unit of heat by up to 1.1628 price per $\mathrm{kWh}$ of the heat for values of $E_{B}=1$.

The addition of virtual heat units used in Austria are less effective because they concern only the risers and do not take into account the operation of the heaters outside the basic state. 
If in individual apartments the consumption values $\mathrm{cv}$ per $1 \mathrm{~m}^{2}$ are similar, the computation methods will provide similar payment values for heating.

If in individual apartments consumption values per $1 \mathrm{~m}^{2}$ are uneven, heat unit prices from methods 1 and 5 are similar, whereas heat unit prices from method 2 are slightly higher.

Methods 3 and 4 are sensitive to the unevenness of $\mathrm{cv} / \mathrm{m}^{2}$ values in individual apartments, as the calculations are based on an overvalued heat unit price and lead to heating receivables that do not correspond to the value of heat consumed.

\section{Conclusions}

Depending on the unevenness of the heat cost allocator's indications, these methods may provide similar or very different results. The presented authors' method, like the calculations made according to German guideline VDI 2077, significantly eliminates the so-called chimneys in the settlements of heating costs for individual flats. It is obvious that apartments in blocks are of similar technical standards: external walls are thermally insulated, and thermal insulation between individual apartments does not apply in Poland. Generally, in new buildings or in buildings after thermal modernization has occurred, external partitions are not a significant component of heat losses. Therefore, the amount of heat loss per $1 \mathrm{~m}^{2}$ in individual apartments is similar, and the receivables for the central heating for $1 \mathrm{~m}^{2}$ of the usable space of such flats should be similar.

Author Contributions: M.A., N.O.K. and V.Z. analyzed the data, results, and equations and made calculations and computations; M.A. and N.O.K. wrote the paper.

Acknowledgments: The authors gratefully acknowledge the financial support for this work from the Ministry of Science and Higher Education of Poland under grant No. WZ/WBiIS/1/2019 of Bialystok University of Technology.

Conflicts of Interest: The authors declare no conflict of interest.

\section{References}

1. Adamski M.; Myszkowska, A. Rozliczanie kosztów ogrzewania na przykładzie wybranego mieszkania, Civil and Environmental Engineering. Civil. Environ. Eng. 2018, 9, 7-14.

2. Adamski M.; Rynkowski, P. Należność za ogrzewanie mieszkania odpowiadająca zużyciu ciepła. Administrator 2015, 11, 26-29.

3. Adamski, M. Pole temperatury powierzchni grzejnika a wskazania podzielnika kosztów. Cieptownictwo Ogrzewnictwo Wentylacja 2017, 48, 2019.

4. Kozydra, N. Porównanie metod rozliczania indywidualnych kosztów ogrzewania w budownictwie wielorodzinnym w Polsce i na Ukrainie, Praca dyplomowa, Politechnika Białostocka. 2018. Available online: https://apd.uci.pb.edu.pl/diplomas/33651/ (accessed on 5 July 2019).

5. Michnikowski, P.; Grzywacz, M. Kryteria sprawdzenia poprawności rozliczania kosztów ogrzewania na podstawie wskazań podzielników. Rynek Instalacyjny 2015, 1-2, 71-74.

6. Michnikowski, P.; Skiba, J. Test poprawności rozliczania indywidualnych kosztów ogrzewania na podstawie wskazań nagrzejnikowych podzielników elektronicznych. Ciepłownictwo Ogrzeewnictwo Wentylacja 2014, 45, 347-351.

(C) 2019 by the authors. Licensee MDPI, Basel, Switzerland. This article is an open access article distributed under the terms and conditions of the Creative Commons Attribution (CC BY) license (http://creativecommons.org/licenses/by/4.0/). 